\title{
GENDERED FAMILY ROLES AND EXPECTATIONS IN TRANSNATIONAL SOMALI REFUGEE FAMILIES: AN EXPLORATORY MULTIPLE-SITE STUDY
}

\author{
Ellinor Rask, Mubarak Warsame, and Klas Borell
}

\begin{abstract}
Studies of transnational families, in which members of the family live in different countries, have mostly focused on families who live apart as a result of economic globalization. However, transnational family life is not only a consequence of the global division of labor but also a consequence of increasing refugee flows. This explorative study is based on interviews with couples in three transnational Somali families, in which different family members either live in their destination country, Sweden, or the transit country, Kenya. The study shows that the geographical distance between the Somali couples has led to a new division of power and duties. The men have less control over the family's economic and social resources, which has allowed the women to exert greater informal power. These changes cannot, however, be seen as permanent changes. The women interviewed worry about how their new life and lifestyle will work out when the family is finally reunited.
\end{abstract}

Keywords: transnational families, refugees, Somalia, Sweden, gender roles

Klas Borell, Ph.D. (the corresponding author) is a Professor of Sociology and Social Work at Jönköping University, Box 1026, 551 11, Jönköping, Sweden. Phone: +46 (0)36 1019 47; Cell phone: +46 (0)70 32406 05. E-mail: Klas.Borell@hlk.hj.se

Ellinor Rask is a Social Work student at Mid-Sweden University, Östersund, Sweden. E-mail: ellie.rask@qmail.com

Mubarak Warsame is a Social Work student at Mid-Sweden University, Östersund, Sweden. E-mail: Duubcad@hotmail.com 
Since the 1990s, most migration scholars recognize that contemporary migrants often participate in relationships that extend across borders, at the same time as they become part of the places in which they settle. Migration is transnational (for research reviews, see Glick Schiller 1997; Kivisto, 2001; Levitt \& Jaworsky, 2007). The family is one of those social fields that crosses national borders and the transnational family has become an increasingly important part of transnational migration studies (for a research review, see Carling, Menjivar, \& Schmalzbauer, 2012). But what is meant by the concept of the transnational family?

A frequently quoted definition states that transnational families are members of the family nuclear unit (mother, father, and children) "that live some or most of the time separated from each other, yet hold together and create something that can be seen as a feeling of collective welfare and unity, namely 'familyhood', even across borders” (Bryceson \& Vuorela, 2002, pp. 3-4). The transnational family illustrates, therefore, the basic conditionality of the relationship between families and households. Families are groups of people bound to one another through emotional ties and moral commitments; households are groups of people bound to a place. Family commitments can coincide with the boundaries of the household, but family relations may also incorporate several households (Borell, 2003).

To acknowledge that family relations can be maintained in spite of the fact that the members of the family are geographically separated is not, however, the same thing as saying that they are unaffected by these conditions. When the members of the family live in different households in two or more countries the relationship between the couple and between other members of the family will be affected in many different ways. The physical distance between the members of the families often also represents changes in the access to resources, in which those that remain in the country of origin are often dependent on those who have employment in the new country (see, for example, Abrego, 2009; Parrenas, 2008; Schmalzbauer, 2008). Furthermore, this sort of structural change within the family is complicated by the fact that the married couple and other members of the family are no longer able to communicate face-toface on a daily basis. The members of a transnational family are obliged to use long-distance communication, these days usually via cheap mobile phone calls (see, for example, Baldassar, 2007; Midianou \& Miller, 2011).

Research into transnational families has been dominated by studies of the experience of economic migrants, and the transnational family form has frequently been exclusively regarded as a consequence of structural forces of economic globalization. Among others (cf., Ho \& Bedford, 2008; Parrenas, 2001), Schmalzbauer (2004) writes that transnational families, "represent a new family form born out of the global economy and reproduced by means of dependence on a transnational division of labor" (p. 1329). But transnational families are not only a consequence of global economic conditions. Refugee flows have increased since the end of the Cold War (Castles, 2003) and contemporary transnational families are, increasingly, a result of this process. The way in which refugees manage to maintain family structures across distance is, however, an understudied issue in migration research (but see, Heger Boyle \& Ali, 2009; Muller, 2008), which has limited the understanding of the challenges facing transnational families. Although economic migrants and refugees may share many common experiences, their situations also differ significantly. 
When families choose to live in two or more countries for economic reasons, they often see this as a temporary arrangement, which will be replaced by a forthcoming reunion either in their country of origin or in the destination country. However, the tougher migration policies in Europe and North America have made it harder for families to reunite in the destination country, which means that transnational families with economic motives now have to face a more long-term separation (Carling et al., 2012). The situation is often even more complicated for refugee families. War and other conflicts often make it impossible for them to reunite in their country of origin, but it can also be difficult for them to reunite in their destination country. The Geneva Convention does in principle grant refugees in one country the right to also bring in their immediate family members, but only if they can prove their identity. This is often very difficult. In a country like Somalia, which is one of the world's largest sources of refugees, there is no state and therefore no authorities that can issue identity papers. As a result of this situation, many refugee families are obliged to live apart in different destination countries or transit countries or in their country of origin. Refugee families that have been split up often face a risk of long-term separation and the uncertainty that a long waiting period involves. How does uncertainty of this kind affect the possibility of maintaining "familyhood" across borders? And what changes arise in the roles of the various family members due to such a prolonged separation?

In earlier research on transnational families much emphasis has been placed on the tenacity of traditional roles within the family (see, for example, Dreby, 2006; Perrenas, 2001). An interesting question is whether this picture of relative continuity in the gender-based roles within the family also applies to transnational refugee families, or if the greater degree of uncertainty these families face obliges them to accept deeper changes in the structure of their gender-based roles.

The aim of this explorative study is to examine issues of this sort through interviewing the members of separated Somali families whose members live either in Sweden, their destination country, or as transit refugees in Kenya.

\section{Somalian Refugees}

Somalia gained its independence in 1960. After a turbulent period of democratization, the country was taken over by the military in a coup d'état in 1969. In the beginning of the 1990s, the military regime collapsed and since then the country has been without an effective central government (Abdullahi, 2001). During the last 30 years, Somalia has experienced one of the world's worst humanitarian crises. Years of fighting between rival warlords, foreign interventions, terrorism, and famine have led to the deaths of up to one million people. The situation in Somalia has generated the world's largest number of refugees, after Afghanistan and Iraq: More than a million people have fled the country and an estimated 1.4 million Somalis, in a nation the United Nations estimates to have a population of nine million, are internally displaced (United Nations High Commission for Refugees, 2012). As a consequence, many Somalis depend on money sent home by relatives from abroad for their survival. This dramatic situation has had many serious consequences for social relations, including gender relations.

The majority of inhabitants in Somalia live as nomads in the countryside, just as their ancestors did (Abdullahi, 2001). The traditional nomadic society has strongly affected the gender and family patterns that have developed. Men and women are seen as complementary opposites, where the women take care of the home and family while the men look after all the contacts with the society at large. Somali men learn at an early age to take responsibility for the security and welfare of their wives. This is demonstrated by the close similarity between 
the Somali words for wife and responsibility (Abdullahi, 2001; Abdi, 2007). Islam is closely related to the Somali identity and has helped to give legitimacy to the patriarchal structure of society (Abdullahi, 2001). The humanitarian catastrophes that Somalia has suffered during the past 30 years have also given rise to increasingly extreme interpretations of Islam, which have contributed to making Somali women increasingly subordinate to men (Abdi, 2007). At the same time, Somali families in exile have had to face challenges that have led to totally different changes. These challenges, however, differ greatly from one another. Somali refugees are now living in many parts of the world under radically disparate conditions: in North America, Australia, Africa, Europe, and in the Middle East. There are many Somali refugees living at present in Kenya, either in refugee camps in Northeastern Kenya, near the Somali border, or in the capital, Nairobi. Many Somali refugees choose to go to Nairobi in the hope that they may be able to take a more active role in improving their life situation. These refugees often lack the protection that official refugee status affords; they are undocumented immigrants and often end up in the suburb called Eastleigh, or "Little Mogadishu". This suburb is famous for its thriving commerce and for the central role it plays for the transnational network of the Somali Diaspora. But Eastleigh is also a place with a high level of crime and with serious social problems (Horst, 2006); undocumented Somali refugees do not have the right to health care and their children have little or no access to the education system (Lindley, 2007).

Innumerable Somali refugees come to Eastleigh hoping to be able to get from there to a country in the West. The increasingly restrictive refugee policies in the West, however, oblige many Somalis to remain in Eastleigh, which results in more and more separated refugee families.

\section{Data and Method}

To our knowledge, the few studies that have been made of transnational refugee families have been based exclusively on interviews with those members of the families who have been granted asylum or residence in a country in the West: Heger Boyle and Ali (2009) have interviewed members of separated Somali families in Minnesota, USA, and Muller (2008) has interviewed members of separated Afghani families in the Netherlands. This must be seen as a serious limitation. A transnational refugee family should, of course, be seen as one unit, but it is nevertheless a unit in which the individual members live apart and in which everyday life is characterized by radically differing social, political, and economic conditions. In view of such asymmetry in the situation of the different family members, it is difficult to make a fair analysis if only those in one place are interviewed. In order to give a more fullscale picture of transnational refugee families, this study has chosen to adopt the multiple-site approach that has become relatively common in studies of the transnational families with a background in economic migration (see, for example, Parrenas, 2008; Schans, 2009; Schmalzbauer, 2008; Wong, 2006. For a general discussion on multi-sited studies, see Marcus, 1995).

This small exploratory study is based on data from repeated interviews with couples in three Somali families whose members live in Kenya and Sweden: in two of the families the children live together with their mothers in Kenya, while their fathers live in Sweden, and in the third family the son lives together with his father in Kenya while the daughter lives with her mother in Sweden.

1. The first family is composed of Faduma and Ali and their eight children. Faduma lives with the children under harsh social conditions in Eastleigh, Kenya. She has no income of her own, but is completely dependent on the money that her husband, Ali, 
can send her from Sweden. Ali is studying Swedish for immigrants and is looking for employment, so far without success.

2. The second family is composed of Isniino and Abshir and their six children. Isniino lives as a single mother with their six children in one small room in Eastleigh. Abshir lives in Sweden where he is studying Swedish and seeking employment.

3. The third family is comprised of Salaad and Asho and their two children. Salaad lives with their son in Eastleigh. He does not have a job and is dependent on financial support from Asho. Asho lives with their daughter in Sweden where she is studying Swedish and plans to get a driving license.

Two rounds of interviews were carried out. The interviews in the first round were conducted during the summer and early autumn of 2011: The spouses in Eastleigh were interviewed in June and the spouses in Sweden were interviewed from August to the end of October. The interviews were carried out face-to-face and took on average about 50 minutes. The conversations were generally conducted in Somali and were relatively unstructured. The interviews were made at a location of the participant's choosing. A general interview guide approach was used (Patton, 2002). Each of the interviewees was asked to describe their life situation, the contact they have with their partner, their relationship to their children, and how they see their future. Themes that arose in the first round of interviews formed the basis for additional questioning in the second round. These follow-up interviews, which were carried out at the end of autumn in the same year, were telephone interviews and took on average about 40 minutes and were also mainly conducted in Somali.

Each of the audio-recorded interviews was transcribed verbatim and translated. A comparative analysis was used to identify themes that emerged from the data (Strauss \& Corbin, 1990); interview data were coded and codes were compared within and between interviews, and were abstracted into concepts and themes.

All names in the study have been replaced with pseudonyms.

\section{Transnational Refugee Families}

Transnational family life is not a new phenomenon. Split household migration was already an integrated part of the experience of Polish migrants a century ago, as can be seen in Thomas and Znaniecki's (1927) classic work The Polish peasant in Europe and America. For a study of the wide scope of experiences of transnational family life in the history of Chinese migrants, see for example Nakano Glenn (1983). But possibilities for bridging the geographical gap between separated family members are now very different. Modern communications make it easier for couples and other family members to stay in touch with one another. In particular, mobile phone calls and international phone cards have enabled the Somali families interviewed to keep in regular contact with one another. When they have not been able to afford telephone cards they have at least been able to keep in touch via MSN messages. Ali, who lives in Sweden, tries to ring his big family in Eastleigh as often as possible. When he can afford it he speaks to his wife and to each of his eight children to hear how each of them is doing, but when he is short of money he makes short calls to his wife or sends an MSN message instead of having an extended call.

Regular phone calls and MSN messages fill a number of functions. All of those interviewed mentioned the emotional importance of talking on the phone. Telephone calls replace face-to-face communication and confirm and maintain the ties between the couple. 
They also help to break the isolation experienced by parents that are obliged to live far away from their children. Asho, who lives with their daughter in Sweden while her husband lives with their son in Eastleigh, says, however, that the telephone calls cannot "replace the longing I feel for the rest of my family".

For members of families that have been obliged to live parallel lives in two very different societies for a long time, difficulties can arise in understanding one another. Asho says that sometimes the conversation can "cause difficulties" and says for example:

When my husband asked our daughter what she wanted for her birthday, she said that she wanted a Hello Kitty computer. He had never heard of that. He had expected her to say that she wanted sweets, which he thought was what all little girls wanted.

The spouses in both Sweden and Eastleigh talk about the difficulty in achieving a common understanding of the family's economy: The spouses in Eastleigh question whether their partner in Sweden really does all that he/she can to help them, while the spouses in Sweden do not know how to explain the limitations of their financial situation.

A recurring issue in their conversations is, of course, the possibility of the family being reunited in Sweden. Both partners tell each other about their contacts with the immigration authorities in Sweden and with the Swedish Embassy in Kenya and they try to work out what the future holds for them, but an equally common topic of conversation are their worries concerning the difficult living conditions in Eastleigh.

\section{A situation without a foreseeable end}

Isniino, who lives with her six children in Eastleigh, says that the social network that she had in Somalia no longer exists in Eastleigh. She adds that most people are fully occupied with their own worries and that her neighbors do not respect her because she is a single mother with six children. When they first came to Eastleigh from Somalia they saw it as short stopover until the family could be reunited in Sweden. Now they have begun to see life in Eastleigh as a temporary situation without a foreseeable end.

The members of the family that live in Eastleigh are obliged to accept that they will be living there for an extended period, although they do not have official refugee status, which would give them access to health care and schools for their children. "We can't return to our country of origin and we have no rights here in Kenya," says Salaad, who lives in Eastleigh with his son.

Faduma, who lives with her eight children in Eastleigh, describes the same desperation regarding their uncertain future:

They [her children] have no future here, we don't have money to pay for their schooling. We aren't here to stay, and that feeling doesn't make it any easier for us to create a future here.

Isniino describes the harsh living conditions there:

It is a tough life here, but it is Allah that decides how we shall survive it. But it isn't easy. I live alone with my eight children on the fifth floor and every night I worry about what might happen. The Police can make a razzia at any moment.

The spouses that live in Sweden are constantly worried about the security of their family members in Eastleigh, and they also experience frustration over not being together with their 
families so that they could influence the situation in which they find themselves. Faduma's husband, Ali, disclosed how frightened he was when his daughter was arrested by the police because she had engaged in a fight with a Kenyan girl, and how he had to send money to his wife so that she could bribe the police to let his daughter go.

\section{Self-esteem}

The strained economic and social conditions that characterize the lives of the family members living in Kenya also affect the lives of those living in Sweden, as shown in the above example. Like numerous other Somali refugees, Abshir has not managed to find employment in Sweden, but still sends three-quarters of the social security benefits that he receives from his Swedish municipality to his family in Eastleigh. "My husband", says his wife Isniino, “does his best. But he doesn't have a job and lives on social benefits, and so he sends us a share of the little that he has. But it by no means covers our costs for room and board.”

Ali says:

I live for my children - they are the reason for my existence. I know how their lives are, without any future, and I can't help them [...] My ambition has been to be a caring father who lives with his children, but war and misery has split up my family and ruined my chances of being a good father. I feel all the time that I am not a good father to my children. I ask myself: How can I cause my children to suffer this? But I have no control over the situation. The hardest question, which keeps me awake at night, is when my children ask me: "Father, why do you spend so much time far away from us? Don't you love us any longer?"

The three men interviewed all express a strong feeling of being at the mercy of a situation that is beyond their control. This feeling of a lack of control is closely related to a feeling of losing their masculinity. The fact that their family has been split up constitutes a challenge to the men's self-esteem as men. Ali, who like Abshir, has not found steady employment in Sweden either, says that he feels that his man's role is called into question:

A real man protects his wife and children. I am not able to do that. I can't support my family. I was brought up to believe that a man should work hard to provide his family with everything they need, but do I do that? No! I can hardly support myself. I and all my family survive thanks to the mercy of the State, which is not exactly what a real man should do. I have done everything, absolutely everything, I can to find a job, but it is impossible.

Abshir dreads the thought of his wife seeing him losing face. "I don't want," he says, "my wife to find out that I can't help her [...] that is something that I can't accept, but what shall I do when this becomes a reality?"

Salaad, who used to support his family as a fishmonger in Mogadishu, but who now lives without any possibility of finding work with his son in Eastleigh, is now supported by his wife who lives in Sweden:

It isn't something I am proud of [...] and in my heart of hearts it's difficult to accept it [...] It is my responsibility as a father to give my children a secure childhood and when I can't do that I have failed as a father [...] A father is always obliged to support his wife and children, not vice versa. It is a quite different thing if I buy toys for my son with money that my wife has sent us, from if I buy toys for him with money I have 
earned myself [...] I will always feel inferior as long as I know that it is my wife that has sent us money and not I that have earned it.

\section{New roles}

Both the wives that live in Eastleigh, as previously mentioned, discuss how vulnerable they feel living apart from their husbands. But the overall picture they give of their lives is considerably more complex. While the women describe their situation as vulnerable, they also make it clear that they are proud that they manage to take care of their children alone. Faduma says:

My husband would never manage living alone with so many children. In spite of the situation and the uncertainty in which we live, I manage to take care of my children [...] I manage to be both mother and father to them.

At the same time, she is uncertain what the consequences of her new lifestyle will be. Has she crossed over a borderline between the male and female roles that can threaten her marriage? Like the other women interviewed, she is worried that her husband may choose to take another wife, which Somali law gives him the right to do. She hopes that her husband will not feel that a significant change has taken place:

I sometimes feel that I do things that a woman shouldn't have to do, according to our traditions, such as negotiating with men, renting an apartment, taking out money and bringing up children in a foreign country [...] But I don't think it will have any negative consequences for my relationship with my husband. I feel secure in my role as a woman and I don't think my husband will think that I have changed.

The changes have been even greater for Asho who lives in Sweden with one of their children. She tells how she was brought up as a young woman to be a good wife and to always take care of her husband. Now, she says, she has other priorities: to help her husband Salaad and her son in Eastleigh to survive. Asho says that telephone calls with her husband, Salaad, can sometimes be strained, but she adds that she tries not to be angry with him "now when he is a single parent with a child in a foreign country." At the same time as Asho looks forward to being reunited with her husband, she wonders how their future relationship will be and how he will cope with the new lifestyle that Asho has established in Sweden. "I have become used to being free and have a new lifestyle that differs from that I had when I lived together with my husband." Asho tries to visualise the problems that will face her when they are reunited in the future and how she will tackle them:

I am a bit worried that he will find the changes too big and too difficult, as it is he that will have to change a lot [...] It's going to be tough for both of us, but I think we'll manage it in the end. Or I hope that we will. I can do without some of the minor things if they would cause my husband to leave me. For example, the driving license that I am studying for and hope to get. I know that my husband cannot prevent me from getting a license, but if he was against it I could do without it. Not only, or primarily, for his sake, but for my children's future and their security.

\section{Discussion and Conclusions}

The transnational approach that gained ground in the 1990s has in many ways contributed to a more complex picture of international migration. But, as with all new and innovative approaches, the transnational approach has often been be overused. Researchers, according to Levitt and Jaworsky (2007), have tended "to see transnational migration 
everywhere, when, in fact, the range and scope of transnational practices of migrants vary considerably” (p. 131; see also Portes, Guarnizo, \& Landolt, 1999). No matter how transnationalism is defined, families having homes in two countries must be a key dimension of transnational migration research. Transnational family life is not a vague, arbitrary indication of cross-border experiences, but a systematic and enduring aspect of relations across international borders. From this perspective, it is not surprising that special attention has been paid to transnational families within transnational migration research. But, although research on transnational families focuses on one of the key elements of transnationalism, it is also characterized by a significant one-sidedness. Transnational families are often assumed to be economic migrants and the transnational family form is seen simply as a result of economic globalization. However, transnational families are not exclusively a result of economic globalization, but also a consequence of present day refugee flows.

The few studies that exist on transnational refugee families are based exclusively on interviews with the members of the families living in the West. The present study is an attempt to use a multiple-site strategy to investigate the asymmetric situation that emerges when members of the same family live under radically differing conditions and how this affects their gendered family roles.

Gendered family roles are not fixed, static roles. Like all social roles, roles in the family are ultimately a question of dynamic relations between people. When certain duties or rights are added or withdrawn from a member of the family the power structure is changed, and this may mean that their role in the family may also alter (see, for instance, Turner, 1990, 2001).

This study shows that the geographic distance between the Somali couples has resulted in a new division of power and duties: The men's control over the economic and social resources has diminished, which has allowed the women to exert greater informal power. The men feel that they have failed in their role as providers for the family, while the women combine their traditional role in the home with a set of new external tasks.

Consequently, the men and women interviewed have had to face difficult issues concerning masculinity and femininity.

The men interviewed all express a common frustration over the fact that as refugees, separated from their families, they are at the mercy of factors beyond their control. This loss of control is primarily seen as a loss of their masculinity. A "real” man should support his wife, not be supported by her.

If becoming a refugee and separating from the family is experienced by the men as a decrease in their sense of self-worth, the women experience almost the reverse. Their lives without their husbands have obliged them to take on new tasks, to become both "mother and father". Wives sometimes feel that life without their husbands has admittedly made them more vulnerable, but has also given them pride in the fact that they have managed to take over many duties that were previously the exclusive prerogative of their husbands. Their pride, however, is combined with concern over the consequences of their overstepping the traditional boundaries between men's and women's roles. All of the Somali wives interviewed are concerned in different ways, and to a greater or lesser degree, about the long-term consequences of this breach of tradition: In the future, when the family is reunited, will my husband accept my new lifestyle and the person I have become, or will our reunion demand a return to the old order? 
In comparison with transnational families that arise through economic migration, transnational refugee families must face greater insecurity. Transnational refugee families cannot reunite in their country of origin and they may have to wait years for the members of the family in a transit land to be reunited with the members in a destination country. In view of this situation, one can say that the Somali refugee women live in two worlds. On the one hand, they are living in the present for an indefinite period of time, and in order to take care of their families they are obliged to perform tasks outside the traditional woman's role. On the other hand, they are also living in the future and have to consider whether their new life and lifestyle will be acceptable if the family is eventually reunited. The women are not, at least at present, prepared to challenge the patriarchal family system, but instead question how much of their current life they will be able to retain without risking their family life and their children's security.

In contrast to earlier studies of transnational refugee families that are based entirely on interviews with family members in a country in the West, the present study attempts to simultaneously consider the importance of different geographic locations. The multiple-site approach of this study gives a more realistic view of the challenges facing transnational refugee families. However, the study also has various limitations. An obvious limitation is the small number of participants involved; the study it is based on repeated interviews with only three families and the results should be interpreted with caution. Another limitation, equally important, has to do with the time frame. The present study shows how the couples try in different ways to visualize the consequences of a future reunion of the family. Longitudinal studies would provide important new insights into how these expectations match with the actual challenges resulting from a future reunion. Unfortunately, longitudinal studies of transnational family life are complicated, but we hope to be able to contribute to this perspective in the near future. 


\section{References}

Abdi, C. M. (2007). Convergence of civil war and the religious right: Reimagining Somali women. Signs, 33(1), 183-207. http://dx.doi.org/10.1086/518393

Abdullahi, M. D. (2001). Culture and customs in Somalia. Westport, CT: Greenwood Press.

Abrego, L. (2009). Economic well-being in Salvadoran transnational families: How gender affects remittance practices. Journal of Marriage and the Family, 71(4), 1070-1085. http://dx.doi.org/10.1111/j.1741-3737.2009.00653.x

Baldassar, L. (2007). Transnational families and the provision of moral and emotional support: The relationship between truth and distance. Identities: Global Studies in Culture and Power, 14(4), 385-409. http://dx.doi.org/10.1080/10702890701578423

Borell, K. (2003). Family and household. Family research and multi-household families. International Review of Sociology, 13(3), 467-480. http://dx.doi.org/10.1080/0390670032000139476

Bryceson, D., \& Vuorela, U. (2002). The transnational family: New European frontiers and global networks. Oxford, UK: Berg. http://dx.doi.org/10.5040/9781474215855

Carling, J., Menjivar, C., \& Schmalzbauer, L. (2012). Central themes in the study of transnational parenthood. Journal of Ethnic and Migration Studies, 38(2), 191-217. http://dx.doi.org/10.1080/1369183x.2012.646417

Castles, S. (2003). Towards a sociology of forced migration and social transformation. Sociology, 37(1), 13-34. http://dx.doi.org/10.1177/0038038503037001384

Dreby, J. (2006). Honor and virtue. Mexican parenting in the transnational context. Gender \& Society, 20(1), 32-59. http://dx.doi.org/10.1177/0891243205282660

Glick Schiller, N. (1997). The situation of transnational studies. Identities, 4(2), 155-166. http://dx.doi.org/10.1080/1070289x.1997.9962587

Heger Boyle, E., \& Ali, A. (2009). Culture, structure, and the refugee experience in Somali immigrant family transformation. International Migration, 48(1), 47-79. http://dx.doi.org/10.1111/j.1468-2435.2009.00512.x

Ho, E., \& Bedford, R. (2008). Asian transnational families in New Zealand: Dynamics and challenges. International Migration, 46(4), 41-62. http://dx.doi.org/10.1111/j.1468-2435.2008.00471.x

Horst, C. (2006). Transnational nomads: How Somali cope with refugee life in the Dalaab Camp of Kenya. Oxford: Oxford University Press.

Kivisto, P. (2001). Theorizing transnational immigration: A critical review of current efforts. Ethnic and Racial Studies, 24(4), 549-577. http://dx.doi.org/10.1080/01419870120049789

Levitt, P., \& Jaworsky, B. N. (2007). Transnational migration studies: Past developments and future trends. Annual Review of Sociology, 33, 129-156. http:/dx.doi.org/10.1146/annurev.soc.33.040406.131816

Lindley, A. (2007). Protracted displacement and remittances: The view from Eastleigh, Nairobi. Oxford: Centre on Migration, Policy and Society, University of Oxford.

Marcus, G. E. (1995). Ethnography in/of the world system: The emergence of multi-sited ethnography. Annual Review of Anthropology, 24, 95-117. http://dx.doi.org/10.1146/annurev.anthro.24.1.95 
Midianou, M., \& Miller, D. (2011). Mobile phone parenting: Reconfiguring relationships between Filipina migrant mothers and their left-behind children. New Media and Society, 13(3), 457-470. http://dx.doi.org/10.1177/1461444810393903

Muller, P. (2008). Connections and disconnections: How Afghan refugees in the Netherlands maintain transnational family relations. Gender, Technology and Development, 12(3), 389-411. http://dx.doi.org/10.1177/097185240901200306

Nakano Glenn, E. (1983). Split household, small producers and dual wage earner: An analysis of Chinese-American family strategies. Journal of Marriage and Family, 45(1), 3546. http://dx.doi.org/10.2307/351293

Parrenas, R. S. (2001). Mothering from a distance: Emotions, gender, and inter-generational relations in Filipino families. Feminist Studies, 27(2), 361-375. http://dx.doi.org/10.2307/3178765

Parrenas, R. S. (2008). Transnational fatherhood: Gendered conflicts, distant disciplining and emotional gaps. Journal of Ethnic and Migration Studies, 34(7), 1057-1072. http://dx.doi.org/10.1080/13691830802230356

Patton, M. Q. (2002). Qualitative research and evaluation methods (3rd ed.). Thousand Oaks, CA: Sage.

Portes, A., Guarnizo, L., \& Landolt, P. (1999). The study of transnationalism: Pitfalls and the promise of an emergent research field. Ethnic and Racial Studies, 22(2), 217-237. http://dx.doi.org/10.1080/014198799329468

Schans, D. (2009). Transnational family ties of immigrants in the Netherlands. Ethnic and Racial Studies, 32(7), 1164-1182. http://dx.doi.org/10.1080/01419870902763852

Schmalzbauer, L. (2004). Searching for wages and mothering from afar: The case of Honduran transnational families. Journal of Marriage and Family, 66(5), 1317-1331. http://dx.doi.org/10.1111/j.0022-2445.2004.00095.x

Schmalzbauer, L. (2008). Family divided: The class formation of Honduran transnational families. Global Networks, 8(3), 329-346. http://dx.doi.org/10.1111/j.1471-0374.2008.00198.x

Strauss, A., \& Corbin, J. (1990). Basics of qualitative research: Grounded theory procedures and techniques. Newbury Park, CA: Sage.

Thomas, W. I., \& Znaniecki, F. (1927). The Polish peasant in Europe and America. New York: Knopf.

Turner, R. H. (1990). Role change. Annual Review of Sociology, 16, 87-110. http://dx.doi.org/10.1146/annurev.soc.16.1.87

Turner, R. H. (2001). Role theory. In J. Turner (Ed.), Handbook of sociological theory (pp. 233-254). New York: Kluwer Academic.

United Nations High Commission for Refugees (UNHCR). (2012). A year of crisis: UNHCR global trends. New York: Author.

Wong, M. (2006). The gendered politics of remittances in Ghanaian transnational families. Economic Geography, 82(4), 355-381. http://dx.doi.org/10.1111/j.1944-8287.2006.tb00321.x 